\title{
清酒中のEDTA の定量分析
}

EDTA のコバルト過酸化水素錯塩による比色定量法

\author{
斎藤 和夫・蓮尾 徹夫・中 野 浩
}

（名古屋国税局鑑定官室）

昭和 43 年 8 月 2 日受理

清酒中の EDTA の定量法として, 戸塚ら1)のコバルトイオンと過酸化水素による定性法をもとに

して，反応条件等の検討を和こない，次の結果を得た。

1）EDTA のコバルトイオンと過酸化水素による発色反応では試料を沸騰させる必要はなく, $60^{\circ} \mathrm{C}$ の加温で充分であり，したがって濃縮による試料の減少を補なう操作の必要が無くなった。

2）過酸化水素水を加兄なければ試料に EDTA を含んでいても発色しないので, 同一試料を定量 用とそのブランクの両方の目的に使用できた。

3）清酒の $\mathrm{pH}$ を 3.0 と調整することにより清酒中の他の成分の影響を無視することができた。

以上の結果をもとに清酒中の EDTA の比色定量を設定した。この方法の定量範囲は EDTA $\mathrm{Na}_{2}$. $2 \mathrm{H}_{2} \mathrm{O}$ の場合 5〜600 ppm（EDTA 雄離酸として 4 470 ppm) であった。

\section{緒言}

食品中の EDTA の分析関して，一般の食品につい ては川城ら ${ }^{2)}$, 下川ら ${ }^{3)}$, 清酒については, 戸塚ら党の報 告がある。これらは, コバルトイオンと過酸化水素によ るEDTA の呈色反応にもとづくもので, 感度, 操作の 容易さ等の点からすぐれた方法と考兄られる。清酒に混 和された EDTA の検出法として戸塚らの方法が用いら れているが，清酒によっては EDTA を含まなくとも明 らかに発色するものがあり，この方法をそのまま定量法 として用いるには不都合があった。

われわれはコバルトイオン-過酸化水素による EDTA の呈色反応条件を検討し，この結果から一応の定量法を 設定し, さらに共存物質の影響についても, 若干の検討 をおこなったので報告する。

\section{実 験 方 法}

1. 装置拉よび試薬

分光光電光度計：日立製 EPU-2 A

$\mathrm{pH}$ メータ：日立堀場製 M-3

試薬

i ) $1 \%$ 硝酸コバルト水溶液 : 硝酸コバルト (JIS K 8552 , 特級) $\mathrm{Co}\left(\mathrm{NO}_{3}\right)_{2} \cdot 6 \mathrm{H}_{2} \mathrm{O} 1 \mathrm{~g}$ を蒸留水にとかして $100 \mathrm{ml}$ とする。 ii）過酸化水素水 $(30 \%)$ : 市販品（JIS K 8230 , 特 級）をそけまま使用する。

iii) $1 / 5 \mathrm{M}$ 酒石酸溶液: 酒石酸 (JIS K 8532, 特級) $30.018 \mathrm{~g}$ を蒸留水にとかして $1 l$ とする。

iv）標準 EDTA：検量線作製のために，同薬化 （株）製 DOTITE $2 \mathrm{NA}\left(\mathrm{EDTA} \cdot \mathrm{Na}_{2} \cdot 2 \mathrm{H}_{2} \mathrm{O}\right.$ ）をそのま ま使用する。以下 $\mathrm{EDTA} \cdot \mathrm{Na}_{2} \cdot 2 \mathrm{H}_{2} \mathrm{O}$ を $\mathrm{EDTA} 2 \mathrm{NA}$ と略記する。

2. 試 料

清酒は, 名古屋国税局管内の原酒掞よび市販酒を用い た。また対照として酶酸一酢酸ナトリウム緩衝液（pH 3 〜4.6) を用い，これらの緩衝液は呈色に対するアルコ ールの影響を考慮して，アルコール分を $20 \%$ とした。

3. 操作法

試料 $10 \mathrm{~m} l$ をとり, これに $1 / 5 \mathrm{M}$ 酒石酸溶液 $2.5 \mathrm{~m} l$, $1 \%$ 硝酸コバルト水溶液 $0.5 \mathrm{ml}$ 㧊よび過酸化水素水 (30\%) $1 \mathrm{ml}$ を加える。 $60^{\circ} \mathrm{C}$ で 40 分間加温後, 冷却 し $530 \mathrm{~m} \mu$ で $10 \mathrm{~mm}$ セルを用いて比色し, その吸光度 $\mathrm{OD}_{10}^{530} a$ とする。別に試料 $10 \mathrm{ml}$ に $1 / 5 \mathrm{M}$ 酒石酸溶 液 $2.5 \mathrm{ml}$ 抢よび $1 \%$ 硝酸コバルト水溶液 $0.5 \mathrm{~m} l$ を 加之, 次いで過酸化水素水のかわりに蒸留水 $1 \mathrm{~m} l$ を加 え, 上と同様の操作を执こなった溶液の吸光度 $\mathrm{OD}_{10}^{530}$ $b$ とすると, 試料中の EDTA による発色は次式によっ て表わされる。 


$$
\Delta \mathrm{OD}_{10}^{\mathrm{s} 30}=(a-b)
$$

定量の場合は清酒の代りに $\mathrm{pH} 3.0$ の酢酸ナトリウ ム一塩酸緩衝液 ( $20 \%$ アルコール溶液)によって EDTA 標準液を調製し, 清酒と同様の操作を扣こなっ作った検 量線から EDTA 含量を算出する（場合によっては反応 後の溶液の $\mathrm{pH}$ を測定し， $3.0 \pm 0.2$ であることを確か める)。

\section{実験結果および考察}

\section{1. 反応温度, 反応時間の検討}

戸塚ら ${ }^{1)}$ の方法をるとにして, 反応温度と時間につい て検討した。 $100^{\circ} \mathrm{C}, 20$ 分間の加熱条件では, 清酒によ っては過酸化水素のため発泡, 突沸するものがある5え アルコール分の蒸発による濃縮が起こるため, 反応後定 容にもどす操作を必要とし, 測定值にもばらつきがあっ た。そこで反応温度を $60^{\circ} \mathrm{C}$ に下げ反応時間を検討した が, 図 1 にしめした結果のよ $5 に 60^{\circ} \mathrm{C}$ で十分反応は進 行した。反応時間は 40 分としたが, この条件では反応 液の濃縮はほとんど起こらないため, 反応後定容にする 操作を省略できた。

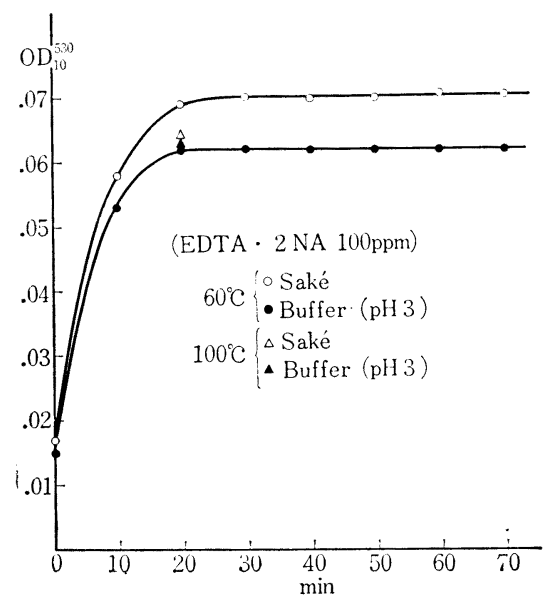

Fig. 1 Reaction time

\section{2. 過酸化水素濃度の検討}

過酸化水素水添加量と発色度の関係について検討を招 こならため， EDTA $2 \mathrm{NA} 50 \mathrm{ppm}$ 添加した清酒抽よ び酢酸-眽酸ソーダ緩衝液 $(\mathrm{pH} 4.6$ アルコール 20\%) そ れぞれ $10 \mathrm{~m} l$ 飞 $1 \%$ 硝酸コバルトを $0.6 \mathrm{ml}$ 過酸化水 素水 $(30 \%)$ を $0 \sim 2 \mathrm{ml}$ 加之（液量 $12.6 \mathrm{ml}$ 一定, 過 酸化水素濃度 $0 \sim 1.62 \mathrm{M})$, 吸光度を測定した。図 2 に しめす結果のよ5に過酸化水素濃度 $0.7 \mathrm{M}(0.9 \mathrm{~m} l$ 添 加）で吸光度はほぼ一定となった。実際の操作では次項 で述べるように $\mathrm{pH}$ 調整のために $2.5 \mathrm{~m} l$ の緩衝液を加
えるので過酸化水素水使用量は $1 \mathrm{~m} l$ とした。この場合 の過酸化水素濃度は $0.73 \mathrm{M}$ である。また図 2 から, 過 酸化水素水を添加しなければ，EDTA を含んだ試料で も発色せず, EDTA 無添加（過酸化水素水添加）のも のとほぼ同じ吸光度をしめした。この結果は過酸化水素 水を添加しなければ EDTA を添加した試料をとのまま EDTA 無添加の試料としても使用できることを意味し，

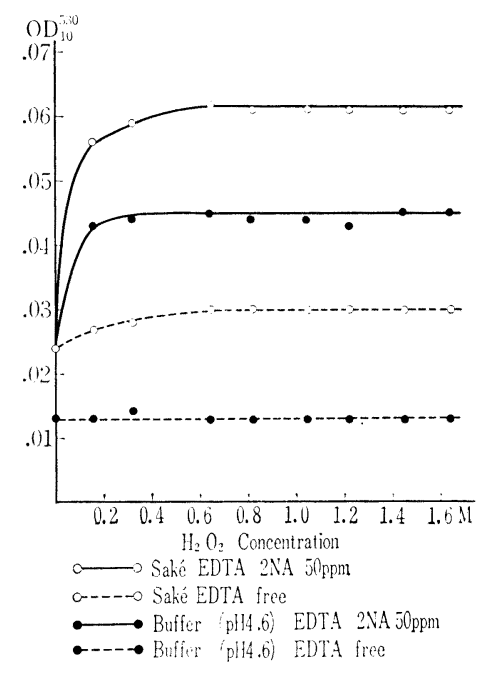

Fig. 2 Effect of $\mathrm{H}_{2} \mathrm{O}_{2}$ Concentration



Fig. 3 Effect of reaction 
EDTA 添加試料しか得られない場合に非常に有利であ る。以上の結果から操作法の項にしめしたように，過酸 化水素水のかわりに蒸留水を加光同様の操作を扣こなっ たものをブランクとして用いることにした。

3. 反応 $\mathrm{pH}$ の検討

清酒扣よび酢酸ソーダ-塩酸緩衝液（20\%アルコール 溶液）の $\mathrm{pH}$ を 2 4.6 とし, EDTA.2 NA $50 \mathrm{ppm}$ 添加したものと, 無添加のものの各々に硝酸コバルト溶 液と過酸化水素水を加え発色させた。結果を図 3 にしめ

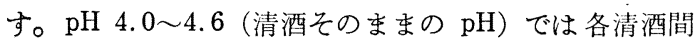
の発色に大きな差があったが， $\mathrm{pH}$ を 3.0 に下げるとこ の差は小さくなり，またその色調もよくそろってきた。 これはコバルトイオンと EDTA のキレート生成が $\mathrm{pH}$ そより制限を受けること, $\mathrm{pH} 4$ 以上では清酒の他の成 分も発色に影響を与えるためと考えられる。以上の結果 から試料の $\mathrm{pH}$ を 3.0 に調整して発色させることにし た。

4. 硝酸コバルト添加量の検討

清酒（pH 3.0 に調整したもの）にEDTA 2 NA を $50 \mathrm{ppm}$ 添加した試料について $1 \%$ 硝酸コバルト水溶液を 0.2 $\sim 1.0 \mathrm{ml}$ の範囲で加え, 過酸 化水素水 $1 \mathrm{ml}$ を加えて発色さ せた（ただし液量は $14.5 \mathrm{ml}$ 一 定)。表1のよ5に発色に差は なかった。下川ら゙) はこの呈色
Table 1

Effect of Cobalt ion amount of $\quad \Delta \mathrm{OD}_{10}^{530}$ $0.2 \mathrm{ml} \quad 0.026$ 0.510 .026 $0.6 \% 0.027$ $0.8 \% 0.027$ $1.0 \% \quad 0.026$
反応に関与するコバルトイオンと EDTA のモル比は 1：1 であることを報告して拉り，硝酸コバルトの添加 量は定量範囲の上限を決定すると考えられる。定量範囲 の面からは硝酸コバルトの量は多い方が良いが，一方で は硝酸コバルト自体が色を持っているため, 余り添加量 を増加させると硝酸コバルト自体の色のため EDTA の 低濃度の場合の比色を困難にすることも考えられる。以 上のことを綜合して試料 $10 \mathrm{ml}$ に対し $0.5 \mathrm{ml}$ の $1 \%$ 硝酸コバルト溶液を添加した。この場合試料中のコバル トイオン濃度は $1.72 \times 10^{-3} \mathrm{M}$ で EDTA 遊離酸（M.
W. 292.24) の量に換算すると $502 \mathrm{ppm}$ ，また EDTA・ $2 \mathrm{NA}(\mathrm{M} . \mathrm{W} .372 .25)$ の量に換算すると $640 \mathrm{ppm}$ と なる。したがって, 本定量法の理論上の定量範团上限は EDTA 2 NA 640 ppm である。

\section{5. 緩衝溶液の検討}

3 項の結果から, 発色は $\mathrm{pH} 3.0$ に調整して扣こなう のが良い事がわかったので, この $\mathrm{pH}$ 調整のための緩衝 液を検討した。すなわち酰酸ソーダ-塩酸緩衝液 $(\mathrm{pH} 1.0$ 拉よび 1.5)，塩酸一塩化カリ緩衝液（ $\mathrm{pH} 1.0 ） ， 1 / 5 \mathrm{M}$ モノクロル酢酸溶液, $1 / 5 \mathrm{M}$ 酒石酸溶液, および $1 / 5 \mathrm{M}$ クエン酸溶液について種々の緩衝能の異なった清酒 10 $\mathrm{m} l$ に各々 $2.5 \mathrm{ml}$ ずつ混合したものに EDTA を添加 乙発色させ $\Delta \mathrm{OD}_{10}^{530}$ のばらつきと反応前後の $\mathrm{pH}$ の変動 等をしらべた。この結果， $1 / 5 \mathrm{M}$ 酒石酸溶液， $1 / 5 \mathrm{M}$ モ ノクロル酢酸溶液または $1 / 5 \mathrm{M}$ クエン酸溶液が 適当で あった。本実験では $1 / 5 \mathrm{M}$ 酒石酸溶液で $\mathrm{pH}$ 調整を括 こなった。

6. EDTA 濃度と発色の関係

6-1 吸収曲線 図 4 にしめすように清酒执よび対照の 緩衝液とも EDTA を添加した試料では 520〜 $530 \mathrm{~m} \mu$ に極大吸収が認められた。緩衝液に EDTA 添加したも のは $380 \mathrm{~m} \mu$ にも吸収を認めているが, 清酒では一般に

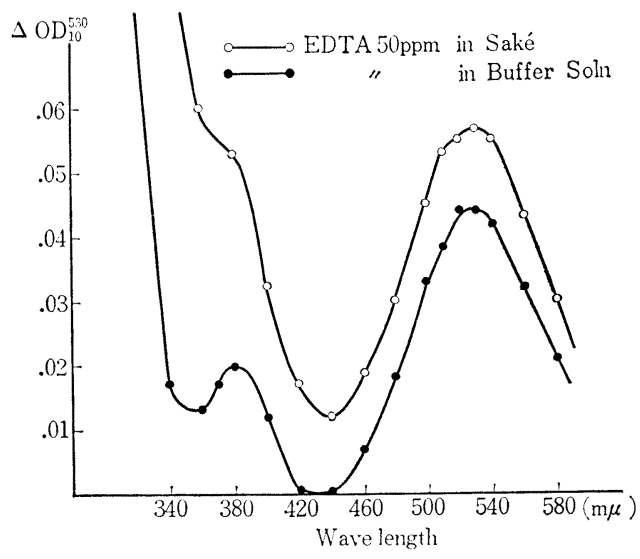

Fig. 4 Absorption Spectrum

Table 2 Effect of Buffer Solutions

\begin{tabular}{|c|c|c|c|c|c|c|c|c|c|c|c|c|c|c|c|c|}
\hline & & \multicolumn{5}{|c|}{$\Delta \mathrm{OD}_{10}^{530}$} & \multicolumn{5}{|c|}{$\mathrm{pH}$ (before reaction) } & \multicolumn{5}{|c|}{$\mathrm{pH}$ (after reaction) } \\
\hline & & A & B & $\mathrm{C}$ & $\mathrm{D}$ & $\mathrm{E}$ & $\mathrm{A}$ & $\mathrm{B}$ & $\mathrm{C}$ & $\mathrm{D}$ & $\mathrm{E}$ & $\mathrm{A}$ & $\mathrm{B}$ & $\mathrm{C}$ & D & $E$ \\
\hline \multirow{2}{*}{$\begin{array}{c}\mathrm{M} / 5 \mathrm{Na} \text {-Acetate- } \\
\mathrm{HCl} \text { Buffer }\end{array}$} & $\left\{\mathrm{ED}^{\prime}\right.$ & .004 & 0 & -0.001 & -0. & 0 & 3. 50 & 3.50 & 3. 70 & 3.60 & 3. 60 & 3. 48 & 3. 52 & 3.70 & 3.63 & 3.58 \\
\hline & [ED] & 3 & 0.06 & 0.057 & & & 0 & 3.55 & & & 60 & 50 & 55 & 70 & & \\
\hline \multirow{2}{*}{ M/5 M. C. A. } & $\{\mathrm{ED}\}$ & 0 & 0.4 & 0.0 & 0 & & 90 & 2.85 & 2.95 & & 2.80 & .92 & 2. 88 & 98 & & \\
\hline & KED & 0 & 0.060 & 0.060 & 0.060 & & 2.95 & 2.90 & 3. 05 & 2.85 & 2. 90 & 2. 90 & 2.88 & 2.98 & 2.85 & 2.8 \\
\hline \multirow{2}{*}{ M/5 Tartaric Acid } & EDT & 0.001 & 0.001 & -0.001 & -0 & 2 & 2.95 & 2. 90 & 3.05 & 2.85 & 2.90 & 2.95 & 2.95 & 3. 05 & 2.90 & 2.9 \\
\hline & $\{$ EI & & & 0.06 & & & 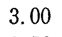 & 2. & 3. & & 2. & 88 & 5 & & 95 & \\
\hline \multirow{2}{*}{$\underset{\text { Buffer }}{\mathrm{M} / 5 \mathrm{KCl}-\mathrm{HCl}}$} & EDT & 1 & 0. & 0 & & . & 2.50 & 2. & 2.70 & 2. & 2. & 50 & 2.60 & 2. & 2.40 & 2. \\
\hline & $\{\mathrm{EDTA}+50 \mathrm{ppm}$ & 0.060 & 0.060 & 0.059 & 0.056 & & 2.50 & 2.55 & 2.80 & 2.45 & 2.40 & 2.60 & 2.60 & 2.78 & 2.40 & 2. \\
\hline \multirow{2}{*}{ M/5 Citric Acid } & $\{$ EDTA & 0.001 & 0.002 & -0.001 & -0.002 & -0 & 3.10 & 3.15 & 3.30 & 3.10 & 3.10 & 3.12 & 3.15 & 3.30 & 3.10 & 3.10 \\
\hline & $\{\mathrm{EDTA}+50 \mathrm{ppm}$ & .059 & 0.058 & 0.056 & 0.057 & 0.059 & 3.10 & 3.20 & 3.40 & 3.20 & 3.10 & 3.15 & 3.30 & 3.10 & 3.10 & 3. \\
\hline
\end{tabular}




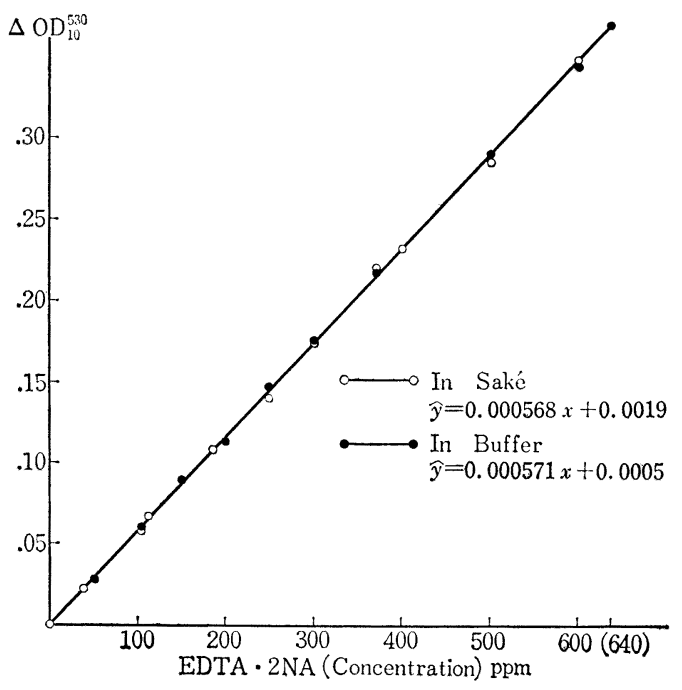

Fig. 5 Calibration Curve of EDTA in Saké and Buffer Soln.
Table 3 Effect of Amino Acids

\begin{tabular}{|c|c|c|c|c|}
\hline \multirow{3}{*}{$\begin{array}{c}\text { Amino Acid } \\
\text { (added } 5000 \mathrm{ppm})\end{array}$} & \multicolumn{4}{|c|}{$\Delta \mathrm{OD}_{10}^{530}$} \\
\hline & \multicolumn{2}{|c|}{ In Saké } & \multicolumn{2}{|c|}{ In Buff $\epsilon$ r Soln } \\
\hline & pH 4.5 & $\mathrm{pH} 3.0$ & pH 4.5 & pH 3. \\
\hline Arginine- $\mathrm{HCl}$ & 0.001 & 0 & 0 & 0 \\
\hline Aspartic Acid & 0.002 & 0.001 & 0.013 & 0 \\
\hline Asparagine & 0.010 & 0 & 0.006 & 0 \\
\hline Glycine & 0.008 & 0 & -0.001 & 0 \\
\hline Sodium Glutamate & 0.029 & 0 & 0 & 0 \\
\hline Proline & 0.005 & 0 & 0 & 0 \\
\hline Tyrosine* & -0.003 & 0 & 0.007 & 0 \\
\hline
\end{tabular}

て，操作法に従って反応させると表 3 にしめすように， $\mathrm{pH}$ 調整を怙こなわない場合，わずかに発色するものも あるが， $\mathrm{pH}$ を 3.0 㒛整することによって呈色は認め られなくなった。緒言でふれたように EDTA 無添加清 酒で，発色が認められたものがあったがそのアミノ酸滴 定值（フォルモル法）とある程度相関関係があった。佐 々木ら ${ }^{4)}$ は食品成分中にコバルトイオン-過酸化水素に よる呈色で EDTA 類似の反応を呈する物質が存在し, これらは遊離の $\alpha-$ アミノ酸であることを報告している。
$400 \mathrm{~m} \mu$ 以下の吸収がかなり大き いため, 比色定量のための波長と しては適当でない。したがって比 色は $530 \mathrm{~m} \mu$ で拈こなうこととし た。

6-2 検量線 清酒, および $\mathrm{pH}$ 3 の緩衝液（20\%アルコール溶 液）に EDTA を添加し, EDTA 濃度と $\Delta \mathrm{OD}_{10}^{530}$ の関係をしらべ た。図 5 にしめすように EDTA. $2 \mathrm{NA}$ 濃度 0 ６00 ppm で直線が えられた。しかし定量範囲の下限 は $10 \mathrm{~mm}$ のセルを用いた場合比 色計の操作上の誤差等を考慮する と EDTA $2 \mathrm{NA} 5 \mathrm{ppm}$ 程度とな る。定量範囲回上限は 4 項でのべ たように $640 \mathrm{ppm}$ が理論值であ るが，さらに EDTA 2 NA を, 700,800 执よび $1000 \mathrm{ppm}$ と増 加させると発色は汇一定となっ た。

\section{7. 共存物質の影響}

清酒中に存在する可能性のある 物質について，発色に影響がある かどうかを検討した。

7-1 アミノ酸の影響 清酒にア ミノ酸をおの拉の $0.5 \%$ 添加し
Table 4 Effect of Saké and Buffer soln.added Reagents

\begin{tabular}{|c|c|c|c|}
\hline \multicolumn{2}{|c|}{ In Saké } & \multicolumn{2}{|c|}{ In Buffer Soln. } \\
\hline Recovery* & Difference* & $\overparen{\text { Recovory }}$ & Difference \\
\hline 100.0 & 0 & 105.9 & 0.001 \\
\hline 100.0 & 0 & 100.0 & 0 \\
\hline 94.1 & -0.001 & 82.4 & -0.003 \\
\hline 100.0 & 0 & 100.0 & 0 \\
\hline 105.9 & 0.001 & 88.2 & -0.002 \\
\hline 88.2 & -0.002 & 100.0 & 0 \\
\hline 100.0 & 0 & 105.9 & 0.001 \\
\hline 105.9 & 0.001 & 105.9 & 0.001 \\
\hline 100.0 & 0 & 100.0 & 0 \\
\hline 117.6 & 0.003 & 111.8 & 0.002 \\
\hline 100.0 & 0 & 100.0 & 0 \\
\hline 105.9 & 0.001 & 94.1 & -0.001 \\
\hline 94.1 & -0.001 & 105.9 & 0.001 \\
\hline 100.0 & 0 & 100.0 & 0 \\
\hline 105.9 & 0.001 & 100.0 & 0 \\
\hline 17.6 & -0.014 & 29.4 & -0.012 \\
\hline 82.4 & -0.003 & 52.9 & -0.008 \\
\hline 88.4 & -0.002 & 41.2 & -0.010 \\
\hline 82.4 & -0.003 & 35.3 & -0.011 \\
\hline 105.9 & 0.001 & 105.9 & 0.001 \\
\hline 105.9 & 0.001 & 105.9 & 0.001 \\
\hline 76.5 & -0.004 & 82.4 & -0.003 \\
\hline 111.8 & 0.002 & 111.8 & 0.002 \\
\hline 88.4 & -0.002 & 94.1 & -0.001 \\
\hline 105.9 & 0.001 & 100.0 & 0 \\
\hline 64.7 & -0.006 & 105.9 & 0.001 \\
\hline 94.1 & -0.001 & 105.9 & 0.001 \\
\hline 105.9 & 0.001 & 94.1 & -0.001 \\
\hline 94.1 & -0.001 & 105.9 & 0.001 \\
\hline 105.9 & 0.001 & 88.2 & -0.002 \\
\hline 94.1 & -0.001 & 111.8 & 0.002 \\
\hline
\end{tabular}


このように $\mathrm{pH}$ 末調整で発色が認められる清酒でも, 本 法のように $\mathrm{pH} 3.0$ に調整することによって発色しなか った。

7-2 活性炭中の呈色物質, 活性炭素（清酒用）

数種を清酒に加え，そのろ液につき本法にしたがって $\Delta \mathrm{OD}_{10}^{530}$ を測定したが呈色しなかった。

7-3 酸, 塩類, その他の物質の影響

清酒に添加される可能性のある物質につき, EDTAを 30 ¿ppm 添加した清酒に，それぞれの物質を $1000 \mathrm{ppm}$ 添加して, 本法に従い反応後 $\Delta \mathrm{OD}_{10}^{530}$ を測定した。同時に EDTA のみ $30 \mathrm{ppm}$ 添加した清酒につき反応後 $\Delta \mathrm{OD}_{10}^{530}$ を測定し，30 ppm EDTA の発色の増減と，回収率を測 定した。表 4 のように，EDTA と類似の呈色を示す物 質は存在しなかったが, アスコルビン酸, シュウ酸,
銅, 鉄およびアルミニウム塩で呈色反応が妨害された。 しかし添加量が $0.1 \%$ と高濃度であることと清酒の場合 は，これらの物質がすでにある程度存在することを考え ると, 通常の含有量では，その影響は少ないと考えられ る。

終りに本実験の御助言，御校閲をいただいた名古屋国 税局鑑定官室，久場真一郎室長，田中利雄主任鑑定官な らびに種々の御援助をいただいた室員諸兄に深謝いたし ます。
文献
1) 户塚 昭, 椎木 钽, 山川浩一郎, 志垣邦雄 : 本誌, 60, (2), 159 (1965)
2）川城䈔, 木村康夫他 : 食品衛生研究, 12，(10)，53 (1960)
3）下川洪平, 堀部信好：食衛誌，9，(2), 35 (1968)
4）佐々木清司, 風村一弘, 川北兵蔵：食衛誌，5，395 (1964) 